\title{
The Comparation of Foreign Financial Investment and Human Investment Effect on Economic in Indonesia Base on Macro Economic Point of View
}

\author{
ENY LESTARI WIDARNI ${ }^{1}$, SURYANING BAWONO² \\ ${ }^{1}$ STIE JAYA NEGARA TAMANSISWA MALANG, INDONESIA, E-mail: enylestarywidarni@stikn.ac.id \\ ${ }^{2}$ STIE JAYA NEGARA TAMANSISWA MALANG, INDONESIA, E-mail: ninobalmy@gmail.com
}

\begin{abstract}
The purpose of this study is to compare the impact of the direction of the relationship between education and health investment with economic growth in Indonesia, with the impact and direction of the relationship of foreign direct investment and portfolio investment with economic growth in Indonesia. This study uses a quantitative method using the Threshold Autoregressive model. This study uses secondary data from the world bank in the annual time period from 2000 to 2019. We found that Investment in education and health has an impact on increasing productivity which drives economic growth because labor productivity directly drives the real sector. However, FDI and FPI changed the financial position in terms of capital. Direct investment increases real capital which has an impact on the creation of new sources of economic production but has consequences in the form of income transfers abroad, resulting in cash outflows. The existence of these foreign transfers continuously when economic conditions are stable and the real sector grows and generates profits that can be greater than the cash inflows obtained when foreign direct investments are made.
\end{abstract}

Keywords: Financial investment; Human investment; Macro-economic.

JEL Classification: E22, M54, M50

Received: June 17, 2021

Accepted: September 20, 2021 


\title{
La Comparación del Efecto de la Inversión Financiera Extranjera y la Inversión Humana en la Economía de Indonesia desde el Punto de Vista Macroeconómico
}

\author{
ENY LESTARI WIDARNI ${ }^{1}$, SURYANING BAWONO² \\ ${ }^{1}$ STIE JAYA NEGARA TAMANSISWA MALANG, INDONESIA, E-mail: enylestarywidarni@stikn.ac.id \\ ${ }^{2}$ STIE JAYA NEGARA TAMANSISWA MALANG, INDONESIA, E-mail: ninobalmy@gmail.com
}

\begin{abstract}
RESUMEN
El objetivo de este estudio es comparar el impacto de la dirección de la relación entre la inversión en educación y salud con el crecimiento económico en Indonesia, con el impacto y la dirección de la relación de la inversión extranjera directa y la inversión de cartera con el crecimiento económico en Indonesia. Este estudio utiliza un método cuantitativo mediante el modelo autorregresivo de umbral. Este estudio utiliza datos secundarios del banco mundial en el período de tiempo anual de 2000 a 2019. Encontramos que la inversión en educación y salud tiene un impacto en el aumento de la productividad que impulsa el crecimiento económico porque la productividad laboral impulsa directamente el sector real. Sin embargo, la IED y la IPF cambiaron la posición financiera en términos de capital. La inversión directa aumenta el capital real, lo que repercute en la creación de nuevas fuentes de producción económica, pero tiene consecuencias en forma de transferencias de ingresos al exterior, que se traducen en salidas de efectivo. La existencia de estas transferencias al exterior es continua cuando las condiciones económicas son estables y el sector real crece y genera beneficios que pueden ser mayores que las entradas de efectivo obtenidas cuando se realizan inversiones directas en el extranjero.
\end{abstract}

Palabras clave: Inversión financiera; Inversión humana; Macroeconomía

Clasificación JEL: E22, M54, M50

Recibido: 17 de Junio de 2021

Aceptado: 20 de Septiembre de 2021 


\section{Introduction}

The Covid-19 pandemic has put pressure not only on the economy but also on education. Education must adapt to the conditions of the covid 19 pandemics. So education must be carried out by adapting to the conditions of covid 19 by implementing health protocols. One of the very big changes related to education during the pandemic is the use of information technology of implementing education (Gandolfi et al., 2021; Qiu et al., 2020). One of the uses of information technology during the pandemic is the implementation of distance learning using information technology and computers known as online learning or online learning. This makes teachers and students unable to interact directly so that it has an impact on learning. However, the use of online learning is one solution to keep learning while maintaining health (Chick et al., 2020; Szymkowiak et al., 2021). One of the uses of information technology during the pandemic is the application of distance learning using information technology and computers known as online learning or online learning. This makes teachers and students unable to interact directly so that it has an impact on learning. However, the use of online learning is one solution to keep learning while maintaining health (Chick et al., 2020; Szymkowiak et al., 2021). Online learning is an alternative to learning during a pandemic. Although not all learning can be taught online, online learning can be a safe learning solution that can be alternative learning that minimizes the risk of covid 19 transmissions. Education cannot be abandoned even though it is in a pandemic period. Education is the key to human resource development and human capital development. Education can increase human capital so that in the future people who follow the educational process can better contribute to the economy and welfare of the country. Of course, in this case, online learning is a practical solution to the educational process in pandemic.

Education is one of the mechanisms in developing human capital. Education is also one of the instruments of human capital investment. Education is very effective in developing human capital. Through education, humans can develop better ways of thinking, logic, and decision-making for themselves. Education not only teaches knowledge and technology development but also provides moral and behavioral teaching so that humans can behave properly and morally. It is important to maintain peace, order, and security. Good behavior encourages a more productive environment. With high productivity, humans are able to work effectively and provide good work results so that humans can continue to increase their income for a better life. When humans develop in terms of income, they have the ability to invest in themselves in the form of better human capital investments. This causes education to be important in developing human capital for work productivity which has an impact on the ability to invest in better human capital in the future so that humans are getting better at earning income and the life they are getting will be better and more comfortable (De Neve \& Fink, 2018; Tang et al., 2021). A good education will encourage people to be healthier, more productive, and happier. Human capital needs to be developed from an early age so that humans have the ability to work and meet their needs independently and increase their ability to invest in human capital so that they can work better and effectively which has an impact on increasing income and increasing living eligibility. It makes people spin in the circle of productivity and investment in human capital. This is good for humans because they get a better life and income growth. Education is important to teach humans to plan and carry out life well. So that education is the main factor in increasing human productivity and human ability to meet the needs of life through work in accordance with their respective skills. The human capital that continues to grow has an impact on human productivity which continues to grow to earn income and a better life.

The pandemic period is a challenge in itself for education. Where normal learning becomes a risk that must be controlled and minimized for health. Education must continue. Online learning is an alternative solution to prevent the transmission of the covid 19 viruses. Online learning is a challenge because online learning is of course different from face-to-face learning. Online learning is not only a challenge for students. But it becomes a big challenge for a teacher. Teaching staff must be able to adapt from online learning. Online learning is also a challenge for those who live in rural areas with 
minimal internet access. Of course, internet access is a major requirement for online learning. When internet access is minimal, it will be an obstacle in online learning. Information technology does not only need to be mastered and utilized for the purposes of supporting the educational process to develop human capital. However, there is also a need for equitable access to technology in remote areas so that everyone can participate in quality learning from home (Rusli et al., 2020; Sukendro et al., 2020). Education empowers teachers to transfer knowledge to students. Not only the transfer of knowledge, but the transfer of skills and morality is also essential in education. Education is very important for human life. Education provides good provisions for students to continue living, develop themselves, develop knowledge and skills so that they can be better prepared to face life and the challenges that exist in life. In developing education, education developers need to develop systematic learning that can be useful for students and can be delivered according to pandemic. Of course, the Covid-19 condition had a impact on education. However, this covid 19 must be overcome and education must continue because if education does not work it can be dangerous for the sustainability of the development of human resources and human capital in the country.

The macroeconomic impact of the pandemic is very impactful. Covid 19 caused a lot of deaths, reducing the population (Qureshi \& Khan, 2020). Another impact is the draining of the mind and time of the population and the government in handling cases of covid 19. Not to mention the policy of restricting mobility. This has a huge impact on various business sectors such as the tourism and transportation sectors. However, the economy has to keep going. Macroeconomically, COVID-19 has spent a lot of government spending in the health sector which has an impact on increasing production in the health sector and has an impact on other sectors. However, restrictions on mobility make production uneven in various sectors so that the distribution of economic growth is reduced and has an impact on the decline in people's purchasing power which threatens the economy. This of course has a massive macroeconomic impact. Covid 19 in addition to having an impact on the production sector, also has an impact on the consumption sector. Human mobility is one of the factors in the rotation of the economy, especially in several vital industries such as transportation and tourism. These two sectors were greatly affected by the covid 19 pandemics. Of course, many large and small companies collapsed and had an impact on the macroeconomic slowdown, increased unemployment, and a decrease in aggregate purchasing power. The impact is very vital for the economy, namely the potential for a decline in gross domestic product or negative growth in gross domestic product. This causes the economy to slow down and potentially a recession and even an economic crisis. Of course, this is very bad if it happens and is not addressed immediately (Altig et al., 2020; Junior et al., 2021).

Economic growth is very important for people's lives. Macroeconomically, economic growth means that people's income is getting better and purchasing power is getting better so that people can live better and more prosperously. This means that people can have a variety of choices of goods and services that can be purchased with good purchasing power. This of course means that humans can have good consumption abilities and enjoy a better and more prosperous life. Where in one period, the gross domestic product becomes an indicator of how many economic factors, namely humans and money, are productive and contribute to the economy. When the gross domestic product grows, it means that the income of the community, if calculated on a macroeconomic basis, is getting bigger and the production of goods and services is increasing, which means that the more goods and services available, the more accessible to the community. When people can reach available goods and services, the level of community prosperity is getting better with a better life. Of course, this is very important because when welfare increases, people can live better, which means they can get better or healthier food and drink and the goods and services needed are of better quality. This is of course a good thing that needs to be pursued for the welfare of the community and people's lives that are getting better (Zhang \& Wang, 2021). Economic growth is one way to get out of the crisis and the threat of an economic recession. The threat of a pandemic is real and has an impact on various sectors. This needs to be addressed immediately and economic growth can be encouraged while maintaining health protocols. Information technology or online factors are very 
helpful in encouraging economic growth ranging from online shopping, online learning to working from home so that the economy can continue to run by minimizing the risk of transmission. Health is an important factor in work productivity and economic growth relies on people's work productivity. When society is productive, economic growth can be achieved and economic recession can be avoided. A pandemic is very risky to human health and has a huge impact on life and the economy. From a macroeconomic perspective, economic growth can be boosted by investing in the real sector and boosting production. Public consumption responds to increasing production in the real sector, government spending, and net exports.

Theoretically, economic recovery indicated by economic growth in the form of GDP can be driven through consumption, investment, government expenditure, and exports. However, if it is drawn to the micro realm, Gross domestic product is a combination of production carried out within the country wherein the micro economy, the production itself is a combination of human and capital elements. Where humans act as actors of production and capital acts as a means of payment to bring in machines and work tools, employee wages, or compensation for humans who carry out production and pay for all things related to production costs. Capital factors in the form of money, can come from within the country or abroad. When capital comes from abroad it is referred to as foreign capital. The foreign capital is used to move the real sector in the form of foreign direct investment and portfolio investment (Huang et al., 2021). Based on two factors of production, namely human and capital (money), this study tries to compare the impact of human capital investment with financial investment originating from abroad, on GDP. in the period of the year before the corona pandemic occurred (before 2020).

\section{Literature Review}

Investment in human capital can have an impact on the ability of people to work. Human capital investment can be influenced by the environment or externalities. Human capital education can be influenced by the environment of friends, family, and work environment. A productive and competitive and healthy work environment can motivate workers to continue to increase their human capital by investing in human capital. Likewise, a productive and active friendship environment that increases the human capital owned also has an impact on triggering the desire to increase the human capital owned. Likewise, a healthy family environment and always encouraging the family to upgrade themselves can encourage increased investment in the human capital of family members (Bosi et al., 2021; Lago Peñas, 2021). The supply of labor ensures a growth path that is balanced with the growth of human capital. Health is an important factor in human capital so that it can be said that health is a supporting factor and even part of human capital itself. Because physical capital is very meaningful in work productivity (Wong, 2021). With a healthy body and sufficient physical capital, capital can be optimized to make the best efforts at work so that work productivity can increase. The better a person's human capital, the more productive that person is. Of course, human capital must be supported by physical capital. This means that physical capital is a person's mental and physical health where a person must be healthy. When a person is healthy, his life is not disturbed. Likewise, when a person becomes sick, his life will be disrupted. Disruption of a person's life due to illness results in decreased productivity so that human capital must be accompanied by physical capital. A healthy physique can optimize the human capital possessed so that they can work better. Physical capital needs to be maintained through health investments ranging from regular exercise, adequate rest, healthy and nutritious food, and good health facilities. When health is maintained, all human capital owned can be optimally empowered in increasing work productivity. Sufficient human capital owned by the community and adequate health facilities has an impact on the availability of good and quality human resources (Zhang \& Wang, 2021).

Healthy financial conditions have an impact on business continuity and the welfare of employees or human resources who work for the company. The financial condition of the company or business sector is essential. The financial health of the business sector has an impact on the welfare of employees. Where when the welfare of employees is good, morale and work motivation will 
increase. When work motivation increases, work productivity can increase properly. Good productivity has an impact on improving the performance of the business sector which has an impact on increasing income and has an impact on the financial health of the business sector. This is a cycle that needs to be maintained so that work productivity and work performance in the business sector, which is the embodiment of the real sector, remains good. When the real sector moves well, economic growth can move well too. When economic growth can move well, the income and welfare of the community will increase. Increased welfare of the community can have an impact on increasing purchasing power which in turn becomes a driver for economic growth. Because public consumption is one of the factors driving economic growth (Bahagia \& Putri, 2020). The use of technology has an impact on better treatment including waste treatment such as carbon emissions. Technology and human capital are inseparable units. Technology is increasingly inseparable from human life. Technology is developed through a knowledge development process that has an impact on technology development as the application of human knowledge. Technology has an impact on human life that is getting better and easier. A good life with good technology has an impact on human development that is getting better. Wherewith good technology humans can learn and develop better. Technological developments and human development go hand in hand in line with human life that is increasingly advanced. Improved technology has an impact on waste management and the development and preservation of the environment better. Technology is a supporting factor in production where technology makes it easier for humans to complete their work so that technology has an impact on human productivity. Better technology will have an impact on better human productivity so that the economy can grow better. A growing economy that is getting better has an impact on human development and better human capital and in the end, has an impact on the development of better technology (Ghosh \& Parab, 2021; Haini, 2021) .

Educational productivity encourages the creation of new industries and the growth of human capital. The development of better and more productive education encourages new skilled workers and has the potential to create new industries and new types of jobs through better technological developments. Good technological development begins with a good education. Because technology is born from knowledge. Technology itself is a manifestation of the development of knowledge. So that education can encourage better technological progress and development. This is certainly a good thing that needs to be encouraged for a better human life. Better education will encourage human productivity and industrial development, which in turn will emerge innovations in various fields, including the development of new products that facilitate human life. Innovation has an impact on human creativity and new products and new industries emerge so that the goods and services produced are increasingly diverse. This of course gives humans a variety of choices so that humans can live better and more prosperous lives. This can be started from the development of good education (Chen, 2020; Gillman, 2021). Education has a very important role. Education encourages people to continue to develop with mastery of skills to improve work in certain fields. Provide knowledge and insight so that they can make better and profitable decisions. Education provides the ability to master new technologies and skills. Education is a proven mechanism capable of developing human abilities called human capital. Human capital is an essential sector in increasing human productivity. Human capital itself also needs to be encouraged by health factors. Humans need to be healthy in order to work well and be productive. Health is not only physical health but mental health. Mental health is needed at work because good mental health can increase morale and stay active. On the other hand, poor mental health can result in depression and other mental health disorders which have an impact on decreasing or even losing human work productivity.

Foreign investment can boost the performance of the business sector when the foreign investment is in the form of foreign direct investment (Solodovnik et al., 2021) . Foreign investment has an impact on increasing business capital in the business sector when foreign investment is in the form of foreign direct investment. Funds obtained from foreign direct investment can be used by the business sector to improve or upgrade its business or business sector for the better. So that foreign investment can play a role in encouraging business performance or industrial performance. The 
impact is that when the real sector's performance increases, it will encourage domestic production, which in turn will encourage gross domestic product, which is an economic indicator of economic growth. The production certainly requires money as a medium of exchange to buy work equipment, employee salaries, and pay for various production needs. One way to get increased capital is a foreign direct investment into the country. A foreign direct investment that enters the country can increase financial capital so that the ability of the business sector to purchase capital goods and recruit the best employees is higher. As a result, the business sector can develop, and the production of goods and services increases. Foreign investment can encourage this so that foreign direct investment greatly contributes to economic growth. With foreign investment, capital will increase and the business sector can buy capital goods and recruit better and more qualified employees. As a result, the productivity of the business sector is increasing. When the business sector increases, production will increase so that the gross domestic product increases which indicate increasing prosperity (Kee et al., 2021; Nair et al., 2021).

When foreign investment enters in the form of foreign direct investment, it means that there are new businesses in the country or old businesses that are being improved. This has a good impact on the business environment when responded wisely. When foreign investment takes place in the form of investment, there is an increase in working capital which has an impact on increasing private sector spending or the business sector so that it can provide a comprehensive multiplayer effect and have an impact on improving the overall business side in the country. The incoming foreign investment in addition to increasing the real business sector from additional capital is also from the multiplayer effect of capital expenditures and the recruitment of new employees. When capital expenditures occur, the capital goods supply sector will be more active because of the arrival of new demand which encourages more capital goods production, and capital goods component spending also has more impact on the capital goods component supply companies also growing and spreading to an increase in employees or the number of people working The more people who work, the purchasing power of the people increases so that the consumption of goods and services also increases, as a result, the real sector is growing well. This continues to rotate so that the economy grows and economic growth creates good welfare. Good welfare means that people are getting richer and living better. People with better living conditions create a better and healthier living environment (Amendolagine et al., 2021).

Foreign direct investment also requires public goods in the form of justice and a sound legal environment. When the legal business environment is healthy, there is an increase in the sense of comfort and security for investors, so that it has an impact on increasing foreign investment which encourages national economic growth. This of course must be supported by the state apparatus and a good and healthy judicial system. A good legal system has an impact on increasing security. For security and publicity to be created properly, the real sector and the business sector can grow well so that human life can be better and people can enjoy life more, as a result, community productivity is getting better, and human ability to invest in human capital is getting better. A good life with a good investment in human capital can develop knowledge, skills, and technology so that new types of industries and jobs can be created and support a better business environment. Legal system support is of course very important because, with a good legal system, businesses can develop better and healthier. This continues to spin so that human civilization can develop in a better direction. The role of education is important in realizing a safe, orderly, peaceful, and prosperous society. This can be realized with good human capital. Apart from good skills, there is also good human morality. So education plays a very important role in this (Kuvvet, 2021).

In contrast to direct investment, portfolio investment, investors' money gathers in the capital market so that it does not flow directly to the real sector. To obtain capital from portfolio investments, the real sector must conduct an initial public offering or IPO or make loans on the money market or through banks. Of course, portfolio investment is about increasing the availability of capital that can be obtained by the real sector but not directly like a direct investment. The foreign direct investment provides additional capital directly to the real sector so that it can directly have an 
impact on increasing the business sector and increasing economic growth. Good economic growth and foreign investment can encourage the pace of production with additional capital from abroad automatically increasing the availability of domestic capital. This is very good because the presence of foreign direct investment implies the existence of new companies or old companies that grow better and the absorption of new workers so that it has an impact on increasing economic participation. With the increase in community work participation automatically community income also increased, and the distribution of income is more evenly distributed, this indicates an increase in people's welfare and high purchasing power so that it has an impact on increasing consumption which encourages the business sector growth.

The role of FDI in encouraging economic growth. Of course, this role must be supported by a good legal system and adequate infrastructure and human resources, both in quantity and quality. Portfolio investment provide additional capital in the real sector, but in a different way. Portfolio investment, both foreign and local, leads to the stock market, wherein the stock market, capital is collected in the stock exchange, namely in the investor's account and to obtain capital, business actors or companies must offer shares to the public so they can obtain additional capital by sells its shares to the public who invest their money in the stock exchange. The existence of new share offerings to the public can be responded to by buying the offered shares. The purchase of shares in the initial offering or sale by the company can be accepted by the company as fresh capital or new capital that can be used to improve the business that has been undertaken. This increases public trust and increases business capacity by the company. So that the products offered by the company can be more acceptable to the public. Of course, this can increase the business of the related company. Investment portfolio plays a role in increasing capital through investment portfolios or better known as paper assets. This is adjusted to the decisions of investors (Asamoah \& Alagidede, 2020). Foreign investment has a very important impact on the economy. However, without education, foreign investment cannot be optimized. Education plays a role in human productivity where education gives humans the opportunity to develop, grow and progress better. Good education and productivity can increase the most important factor in production, namely humans. Humans are the most important factor of production because without humans there is no production and no business can operate without humans operating it. So that the role of education and investment into a unified whole. Domestic investment can be strengthened by foreign investment because with foreign investment there will be additional funds to improve the business sector so that the business sector can develop better and encourage economic growth. Of course, this needs to be supported by quality human resources so that they can maximize the available capital to do their best as a form of contribution to the economy with various fields of human expertise.

\section{Research Method}

In this study, the type of research used is explanatory research which serves to explain the relationship between the dependent variable and the independent variable and another purpose is to explain the relationship between variables through hypothesis testing. The independent variables in this study are education investment and health investment, portfolio investment, and foreign direct investment. While the dependent variable is economic growth which is indicated by gross domestic product.

The unit of analysis in this study is the population in Indonesia and foreign investment. By using the dependent variable, namely economic growth, while the independent variables consist of education investment and health investment, foreign direct investment, and portfolio investment in Indonesia. To achieve the research objectives, it is necessary to analyze the behavior of the data so that it can be seen the behavior of the data from each variable, both the dependent variable and the independent variable which is the object of research. One of the analytical tools to observe the behavior of the data so that it can be known the direction of the linear and non-linear relationship of each data variable and forecasting of the dependent variable from the accumulated behavior of the 
independent variable data on the dependent variable cumulatively in the timeline of the research period, namely Threshold Autoregressive.

This study uses a quantitative method using the Threshold Autoregressive model to understand the behavior of data from education investment, health investment, and economic growth in Indonesia with econometric equation as follows:

$$
Y_{t}=\beta_{0}+\beta_{t 1} E d_{t 1}+\beta_{t 2} H_{t 2}+e_{t}
$$

Where,

$$
\begin{aligned}
& Y=\text { Economic Growth } \\
& T=\text { Time series } \\
& \beta=\text { Intercept } \\
& E d=\text { Educational Investment } \\
& H=\text { Health Investment } \\
& E=\text { Error Terms }
\end{aligned}
$$

$$
Y t=0+t 1 F D I t 1+t 2 F P I t 2+\text { et }
$$

Where,

$\mathrm{Y}=$ Economic Growth

$\mathrm{T}=$ Time series

$\beta=$ Intercept

$\mathrm{FDI}=$ Foreign Direct Investment

$\mathrm{FPI}=$ Portfolio Investment

$\mathrm{E}=$ Error Terms

The research period in this study is the annual period from 2000 to 2019.

\section{Results and Discussion}

To find out the behavior of data on education investment, health investment and economic growth in Indonesia in the annual research period from 2000 to 2019, the Threshold Autoregressive estimation was carried out, with the following results:

GDP $=(7.45952198212 *$ EDUCATION $+23.2256350465 *$ HEALTH $)+(6.34956415475 *$ EDUCATION 9.29148060505*HEALTH)*@LOGIT(4.37504550276e-11*(GDP(-3)-832902892740)) + 62326926652.2

From the results of the Autoregressive Threshold estimation, it can be seen the direction of the relationship between each variable in the non-linear and linear parts which are summarized in Table 1.

The education variable, which is an indication of the movement of education investment data, has a positive relationship with economic growth in both the linear and nonlinear parts, which means that every change in education data or education investment has a positive impact or encourages economic growth. Where the greater the investment in education, the greater the impact on economic growth in the future. However, it is different from health investment. Health investment is positive in the linear part and negative in the non-linear part, which means that there are two conditions where the first condition is when the majority of the population is healthy and health investment encourages economic growth because it is maintenance. However, when the majority are sick, health investment acts as a restorer of human health which has an impact on decreasing productivity because it does not have a direct impact on economic growth when there is a spike in health cases in Indonesia. This can be described in the forecasting in Figure 1. 
The Comparation of Foreign Financial Investment and Human Investment Effect on Economic in Indonesia Base on Macro Economic Point of View

Table 1 First Estimation Results

\begin{tabular}{|c|c|c|c|c|}
\hline Variable & Coefficient & Std. Error & t-Statistic & Prob. \\
\hline \multicolumn{5}{|c|}{ Threshold Variables (linear part) } \\
\hline EDUCATION & 7.459522 & 3.348716 & 2.227577 & 0.05 \\
\hline HEALTH & 23.22564 & 3.74924 & 6.194757 & 0.0001 \\
\hline \multicolumn{5}{|c|}{ Threshold Variables (nonlinear part) } \\
\hline EDUCATION & 6.349564 & 5.063194 & 1.254063 & 0.2383 \\
\hline HEALTH & -9.291481 & 6.236555 & -1.489842 & 0.1671 \\
\hline \multicolumn{5}{|l|}{ Non-Threshold Variables } \\
\hline C & $6.23 \mathrm{E}+10$ & $9.39 \mathrm{E}+09$ & 6.638313 & 0.0001 \\
\hline \multicolumn{5}{|l|}{ Slopes } \\
\hline & & & & \\
\hline SLOPE & $4.38 \mathrm{E}-11$ & 8.39E-11 & 0.521279 & 0.6135 \\
\hline \multicolumn{5}{|l|}{ Thresholds } \\
\hline & & & & \\
\hline THRESHOLD & $8.33 \mathrm{E}+11$ & $9.34 \mathrm{E}+10$ & 8.917837 & 0 \\
\hline
\end{tabular}

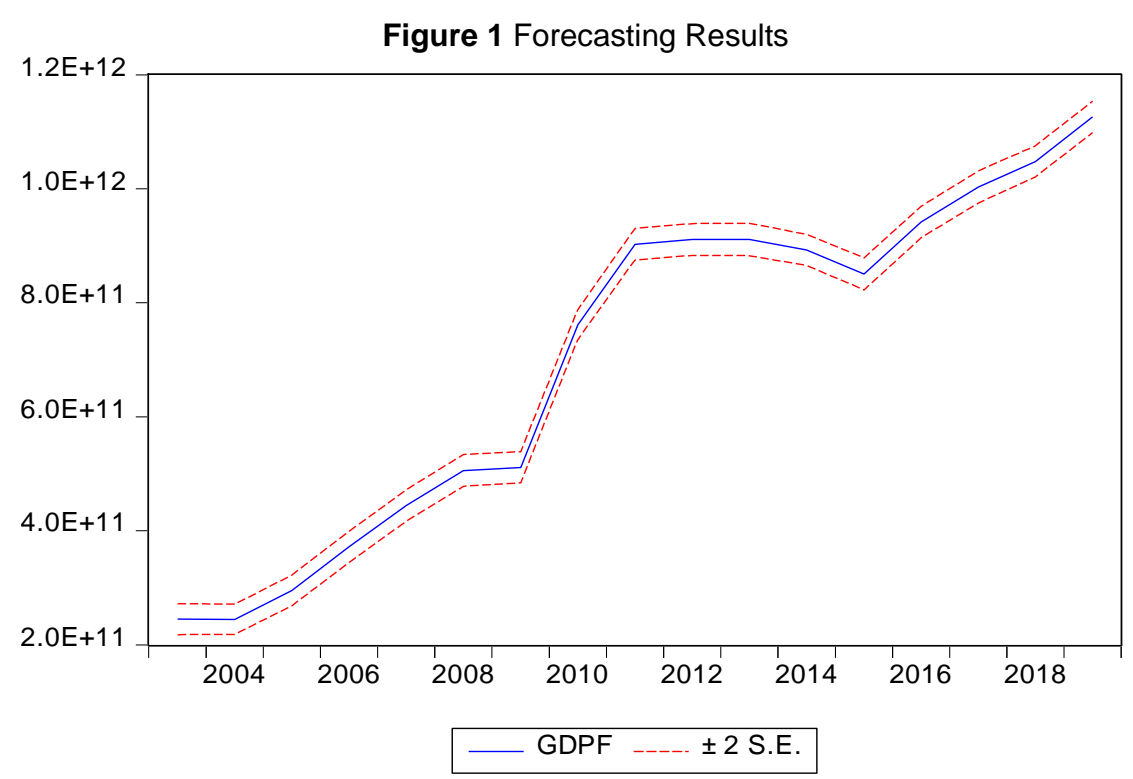

From the results of forecasting in Indonesia, education, and health, in general, encourage economic growth, however, when a shock occurs, education is the driving force and health is healing, which means it becomes consumption that does not directly encourage economic growth. To find out the behavior of data in the annual research period from 2000 to 2019, the Threshold Autoregressive estimation was carried out, with the following results:

$$
\mathrm{GDP}=(-3.29188082665 * \mathrm{FDI}+141.673343007 * \mathrm{PORTFOLIO})+(13.9471083304 * \mathrm{FDI}-
$$
149.013252139*PORTFOLIO)*@LOGIT(1.39416223666e-11*(GDP(-3)-223602246565)) 615448561937

From the results of the Autoregressive Threshold estimation, it can be seen that the direction of the relationship between each variable in the non-linear and linear parts is summarized in Table 2 below: 
Table 2 Second Estimation Results

\begin{tabular}{|l|c|c|c|c|}
\hline \multicolumn{1}{|c|}{ Variable } & Coefficient & Std. Error & t-Statistic & Prob. \\
\hline & & & & \\
\hline Threshold Variables (linear part) & & & & \\
\hline & & & & \\
\hline FDI & -3.291881 & 41.76478 & -0.07882 & 0.9387 \\
\hline PORTFOLIO & 141.6733 & 129.3586 & 1.095198 & 0.2991 \\
\hline & & & & \\
\hline Threshold Variables (nonlinear part) & & & & \\
\hline & & & & \\
\hline FDI & 13.94711 & 43.24349 & 0.322525 & 0.7537 \\
\hline PORTFOLIO & -149.0133 & 128.5412 & -1.159264 & 0.2733 \\
\hline & & & & \\
\hline Non-Threshold Variables & & & & \\
\hline & & & & \\
\hline C & $6.15 \mathrm{E}+11$ & $1.18 \mathrm{E}+11$ & 5.218646 & 0.0004 \\
\hline & & & & \\
\hline Slopes & & & & \\
\hline & & & & \\
\hline SLOPE & $1.39 \mathrm{E}-11$ & $8.51 \mathrm{E}-12$ & 1.638412 & 0.1324 \\
\hline & & & & \\
\hline Thresholds & & & & \\
\hline THRESHOLD & & & & \\
\hline
\end{tabular}

Based on the estimation results, foreign financial investments both encourage economic growth. However, there is a difference in motivation. Portfolio investment provides a boost when the economy is stable and there are no upheavals or shocks. When the economy is stable, portfolio investment has a positive direction, which will encourage the economy. However, direct investment is just the opposite. This is because direct investment is encouraging in the short term by increasing cash inflow. However, when the company or direct investment operates, there will be a transfer of income abroad which actually suppresses economic growth. FDI or foreign direct investment can boost the economy and become a tool to assist economic recovery when an economic shock occurs. With FDI during times of economic turmoil, it can provide additional capital to rise and produce and provide multiplayer effects. When operating, there is an economic generation which when it has not reached stability it is almost difficult to transfer income because economic benefits can be generated when there is economic stability. However, in contrast to portfolio investment, when there is an economic shock, portfolio investment, especially foreign debt, will suppress economic growth because of the interest expense. Portfolio investment in the capital market only provides positive sentiment on paper in the form of strengthening stock prices, however, it does not reflect real business conditions. The money invested in portfolio investment will pool in the money pool of the capital market or stock exchange and it is difficult to withdraw it to real capital when economic conditions are not good or shaken and will be exacerbated when there is the bankruptcy of many companies which results in depreciation of the investment value in portfolio investments. Based on the estimation results, it can be seen that investment can encourage economic growth, however, foreign investment in this study shows that the addition of capital provides a temporary growth boost. Foreign investment has a cost, namely the transfer of income to foreign investors so that there is a cash out flow which means that domestic money will be reduced. So that foreign investment must be utilized optimally and large. The impact of foreign investment on the economy can be forecasted. This can be described in the forecasting in Figure 2 below: 


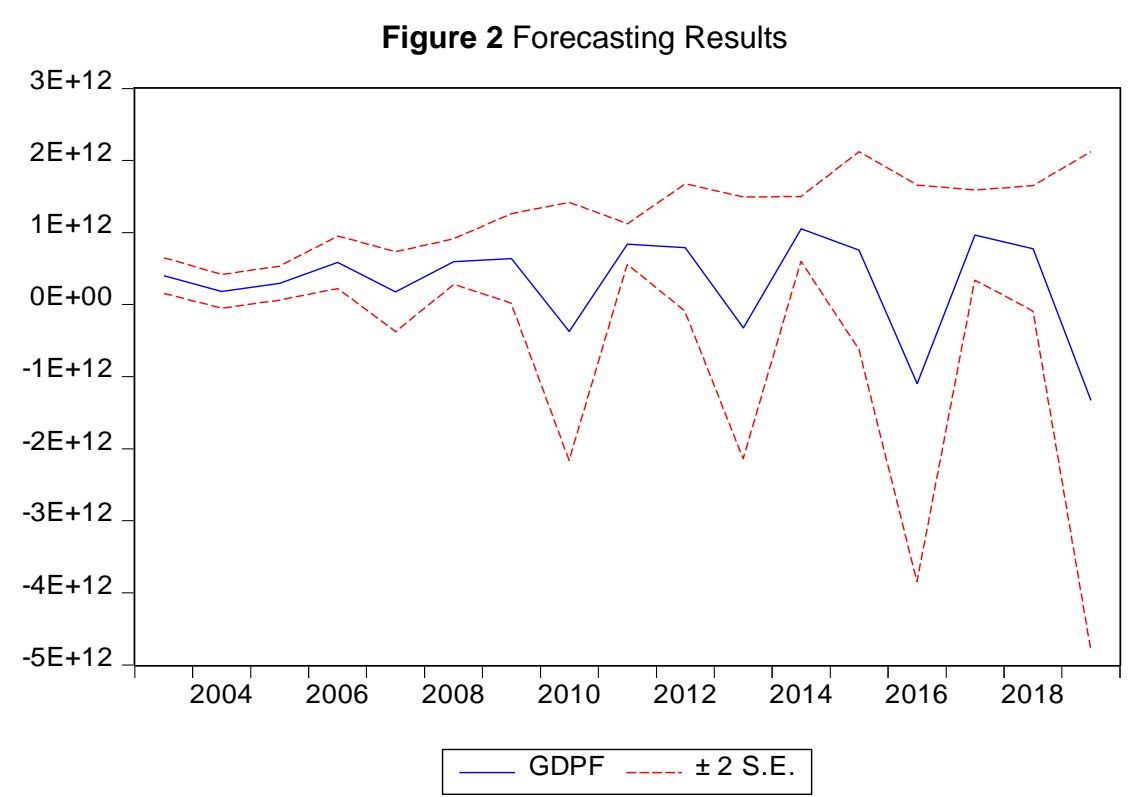

From the forecasting results that take into account the impetus of FDI and FPI to economic growth, it becomes bumpy as the forecasting results in Figure 4.2. This shows that foreign financial investment is not the main driver of the economy in Indonesia. This is indicated by a bumpy graph and other factors are needed to help drive economic growth. FDI has an impact on increasing cash inflows in the real sector and creating new production sources or new production support. However, FDI has the consequence of cash outflows in the form of larger income transfers abroad because investment is profit-oriented, which means that money entering the country as a result of FDI will encourage new production sources that generate profits transferred abroad where transfers abroad are cash outflows. Which will continuously be greater than the cash inflow generated, especially when economic conditions are stable. The investment portfolio causes the pool of money in the capital market to get bigger and does not directly convert into real capital that can be used by the real sector. When in stable conditions the capital pool on the capital market can be withdrawn by the real sector through an IPO so that capital can flow to the company to increase productivity. However, when an economic shock occurs, it is on the contrary that the money pool in the stock exchange is difficult to convert into real capital and there is a tendency to depreciate the value of capital due to the decline in stock prices which suppresses the productivity of the real sector which in turn has an impact on suppressing economic growth. From the forecasting results, it can be seen that the encouragement given to economic growth is not as great as the pressure exerted by foreign investment. Because foreign investment is an additional capital to provide a temporary boost and should be used as a momentum to provide a better boost. Of course, foreign investment has an impact on cash outflow and puts pressure on economic growth so that the forecasting graph of the relationship between FDI and GDP is depicted as a forecasting graph. This is because the cash outflow in the long term will be greater than the cash inflow when the foreign investment is obtained because investors expect profits so that the money invested can be obtained greater. That is why the pressure on future economic growth is greater than the push on economic growth when foreign investment is obtained. However, the multiplayer impact when foreign investment is obtained is large enough that it must be responded to by the human capital factor which is the main driver of economic growth in Indonesia. So that human capital investment cannot be ignored and is the main investment for all Indonesian people.

\section{Conclusion}

Investment in education and health has an impact on increasing productivity which drives economic growth because labor productivity directly drives the real sector. However, FDI and FPI changed the financial position in terms of capital. Direct investment increases real capital which has 
an impact on the creation of new sources of economic production but has consequences in the form of income transfers abroad, resulting in cash outflows. The existence of these foreign transfers continuously when economic conditions are stable and the real sector grows and generates profits that can be greater than the cash inflows obtained when foreign direct investments are made. So that foreign direct investment actually suppresses long-term productivity due to cash outflows in the form of income transfers. Portfolio investment (FPI) increases the pool of money in the capital market is channeled into the real sector when the issuance of capital securities in the form of shares or debt securities is held. And the letter is for sale. When a foreign portfolio investment enters, the investor buys the letter so that the incoming capital settles in the capital market and or money market money pool. When domestic investors make withdrawals, it can become cash inflow because money is attracted to the real sector which can be used by investors to consume or invest in the real sector. However, when foreign investors withdraw their money, there is a cash outflow. When economic conditions are stable, the investment portfolio can encourage economic growth. However, when economic conditions are unstable, the opposite happens. Foreign investment is a trigger, not the main driver. In fact, the main driver of the economy is an investment in human capital.

\section{References}

1. Altig, D., Baker, S., Barrero, J. M., Bloom, N., Bunn, P., Chen, S., Davis, S. J., Leather, J., Meyer, B., \& Mihaylov, E. (2020). Economic uncertainty before and during the COVID-19 pandemic. Journal of Public Economics, 191, 104274.

2. Amendolagine, V., Lema, R., \& Rabellotti, R. (2021). Green foreign direct investments and the deepening of capabilities for sustainable innovation in multinationals: Insights from renewable energy. Journal of Cleaner Production, 310, 127381.

3. Asamoah, M. E., \& Alagidede, I. P. (2020). Exploring the causal relationships and allocation puzzle between portfolio investments and real sector growth in Sub-Saharan Africa. Research in International Business and Finance, 52, 101187.

4. Bahagia, R., \& Putri, L. P. (2020). Factors Affecting Employee Performance During the Covid Pandemic 19. Journal of International Conference Proceedings (JICP), 3(4), 31-35.

5. Bosi, S., Lloyd-Braga, T., \& Nishimura, K. (2021). Externalities of human capital. Mathematical Social Sciences, 112, 145-158.

6. Chen, C. (2020). Capital-skill complementarity, sectoral labor productivity, and structural transformation. Journal of Economic Dynamics and Control, 116, 103902.

7. Chick, R. C., Clifton, G. T., Peace, K. M., Propper, B. W., Hale, D. F., Alseidi, A. A., \& Vreeland, T. J. (2020). Using technology to maintain the education of residents during the COVID-19 pandemic. Journal of Surgical Education, 77(4), 729-732.

8. De Neve, J.-W., \& Fink, G. (2018). Children's education and parental old age survival-Quasiexperimental evidence on the intergenerational effects of human capital investment. Journal of Health Economics, 58, 76-89.

9. Gandolfi, E., Ferdig, R. E., \& Kratcoski, A. (2021). A new educational normal an intersectionality-led exploration of education, learning technologies, and diversity during COVID-19. Technology in Society, 66, 101637.

10.Ghosh, T., \& Parab, P. M. (2021). Assessing India's productivity trends and endogenous growth: New evidence from technology, human capital and foreign direct investment. Economic Modelling, 97, 182-195.

11.Gillman, M. (2021). Steps in industrial development through human capital deepening. Economic Modelling, 99, 105470.

12. Haini, H. (2021). Examining the impact of ICT, human capital and carbon emissions: Evidence from the ASEAN economies. International Economics, 166, 116-125. 
13.Huang, Y., Xie, E., \& Wu, Z. (2021). Portfolio characteristics of outward foreign direct investment and dynamic performance of emerging economy firms: An option portfolio perspective. International Business Review, 30(4), 101750.

14.Junior, C. J. C., Garcia-Cintado, A. C., \& Junior, K. M. (2021). Macroeconomic policies and the pandemic-driven recession. International Review of Economics \& Finance, 72, 438-465.

15.Kee, D. M. H., Hisam, N. N. B. N., Abd Rashid, N. H. B., Aziz, N. S. B. A., Mazlan, N. A. B., \& Mahadi, N. A. Z. B. (2021). The Impact of Using Cashless Payment during the Covid-19 Pandemic: A Case Study of Maybank. International Journal of Accounting \& Finance in Asia Pasific (IJAFAP), 4(2), 107-117.

16.Kuvvet, E. (2021). Anti-corruption courts and foreign direct investments. International Review of Economics \& Finance, 72, 573-582.

17.Lago Peñas, I. (2021). Transaction costs in electoral coordination: how turnout shapes changes in the number of parties. Electoral Studies. 2021 May 18; 72: 102349.

18.Nair, R. K., Reddy, L. S., Verma, P., Pandey, R., Yuwono, S., Sin, L. G., Qi, W. Y., Kee, D. M. H., Gee, O. X., \& Ing, T. W. S. (2021). The Impact of COVID 19 Towards International Business Strategy: A study of Coca-Cola Company. International Journal of Accounting \& Finance in Asia Pasific (IJAFAP), 4(2), 73-92.

19.Qiu, H., Li, Q., \& Li, C. (2020). How technology facilitates tourism education in COVID-19: Case study of nankai university. Journal of Hospitality, Leisure, Sport \& Tourism Education, 100288.

20.Qureshi, M. I., \& Khan, N. (2020). Impact of COVID-19 CORONAVIRUS PANDEMIC on sustainable development goals: What we learn from the past and where we are heading? Systematic Literature Review and Meta-Analysis Journal, 1(1), 30-47.

21.Rusli, R., Rahman, A., \& Abdullah, H. (2020). Student perception data on online learning using heutagogy approach in the Faculty of Mathematics and Natural Sciences of Universitas Negeri Makassar, Indonesia. Data in Brief, 29, 105152.

22.Solodovnik, O., Zhemoyda, O., Soroka, A., Matsola, S., Tytarchuk, I., \& Bielialov, T. (2021). Innovative development of the foreign economic activity of the enterprise. Studies of Applied Economics, 39(3).

23.Sukendro, S., Habibi, A., Khaeruddin, K., Indrayana, B., Syahruddin, S., Makadada, F. A., \& Hakim, H. (2020). Using an extended Technology Acceptance Model to understand students' use of elearning during Covid-19: Indonesian sport science education context. Heliyon, 6(11), e05410.

24.Szymkowiak, A., Melović, B., Dabić, M., Jeganathan, K., \& Kundi, G. S. (2021). Information technology and Gen Z: The role of teachers, the internet, and technology in the education of young people. Technology in Society, 65, 101565.

25.Tang, L., Sun, S., \& Yang, W. (2021). Investments in human capital: The evidence from China's new rural pension scheme. Research in International Business and Finance, 55, 101345.

26.Wong, S. K. (2021). Sustainable Livelihood Strategies of The Riverine Communities at Sadong Jaya, Sarawak, Malaysia: Role of Capital Assets. Studies of Applied Economics, 39(1).

27.Zhang, X., \& Wang, X. (2021). Measures of human capital and the mechanics of economic growth. China Economic Review, 101641. 